\author{
S. Popovici, E. Kaiser
}

\title{
A BURIAL MOUND IN THE TOWN OF CIMIŞLIA IN SOUTHERN PART OF THE REPUBLIC OF MOLDOVA: RELATIVE AND ABSOLUTE CHRONOLOGY OF THE BURIALS
}

The grave mound 8 the in city of Cimişlia, Republic Moldova is located on the first terrace of the Cogâlnic River. Burials from the Eneolithic to the Sarmatian period, a ditch and cult structure have been discovered in $i t$. The relative and absolute dating of the burial series of the Eneolithic - Early Bronze Age is being clarified.

Keywords: Late Eneolithic, Zhivotilovka culture, absolute chronology, Yamnaya culture.

Sergiu Popovici and Ion Ciobanu excavated grave mound 8 in the town Cimişlia, Republic Moldova, in 2015 (Popovici et al. 2016) ${ }^{1}$. Radiocarbon analyses were conducted of several burials and features found in this mound. As Vitalii Otroshchenko was always interested in defining and refining the absolute chronology of Eastern European Bronze Age, we dedicate this article to him.

The mound was situated on the first terrace of the small river Cogâlnic, $16 \mathrm{~m}$ above the river (fig. 1), and was one of a group of six burial mounds there. Because of intensive ploughing activity, the mound was only $0.8 \mathrm{~m}$ in height when the excavation began. It measured $36 \mathrm{~m}$ in diameter. Although rather simple in terms of its stratigraphy, it yielded several interesting features and finds: ten graves dating to periods ranging from the Eneolithic to the Sarmatian periods, a ring-ditch, six postholes interpreted as remnants of a cult structure and two accumulations of animal bones and artefacts (fig. 2). A first layer was erected above the central Eneolithic grave, Grave 3, a second was built above Grave 6,

1. The authors are grateful to Dr. Denis Topal and Alison Borrowman for their help with the English translation.

(C) S. POPOVICI, E. KAISER, 2021 a Yamnaya burial. Table 1 gives an overview of the character and the relative chronology of all features excavated. Anthropological investigations were carried out by Dr. Angela Simalcsik (Iaşi), and Dr. Roman Croitor conducted zooarchaeological research.

In this contribution we concentrate on the chronology of the graves and other features found in the tumulus. Ten radiocarbon samples were analysed for the following purposes.

1) To determine when Grave 3, the primary grave, was constructed.

2) To determine the age for Grave 4, which could not be dated without radiocarbon data due to the poor state of preservation and the lack of inventory.

3) To determine the chronological relationships among the various burials and features (ditch, cult complex) of the Late Eneolithic.

4) To obtain dates for the two graves of the Zhivotilovka culture (fig. 3) in order to enlarge the series of absolute dates for this archaeological culture, as few radiocarbon dates have been obtained for Zhivotilovka graves until recently.

5) To obtain dates for the Yamnaya culture burials. The number of radiocarbon dates obtained for Yamnaya complexes excavated in the Republic Moldova and in the Northwest Pontic region is still limited. Obtaining additional dates was therefore of considerable interest, particularly given the ongoing debate about the absolute chronology of the Yamnaya culture as a whole.

Methods. Ten samples were sent to the Radiocarbon Laboratory in Poznań, where they were dated by Prof. Dr. Tomasz Goslar and his team. Six of the samples were human bones taken from the burials after they had been studied by Dr. Angela Simalcsik. One sample was an animal bone 


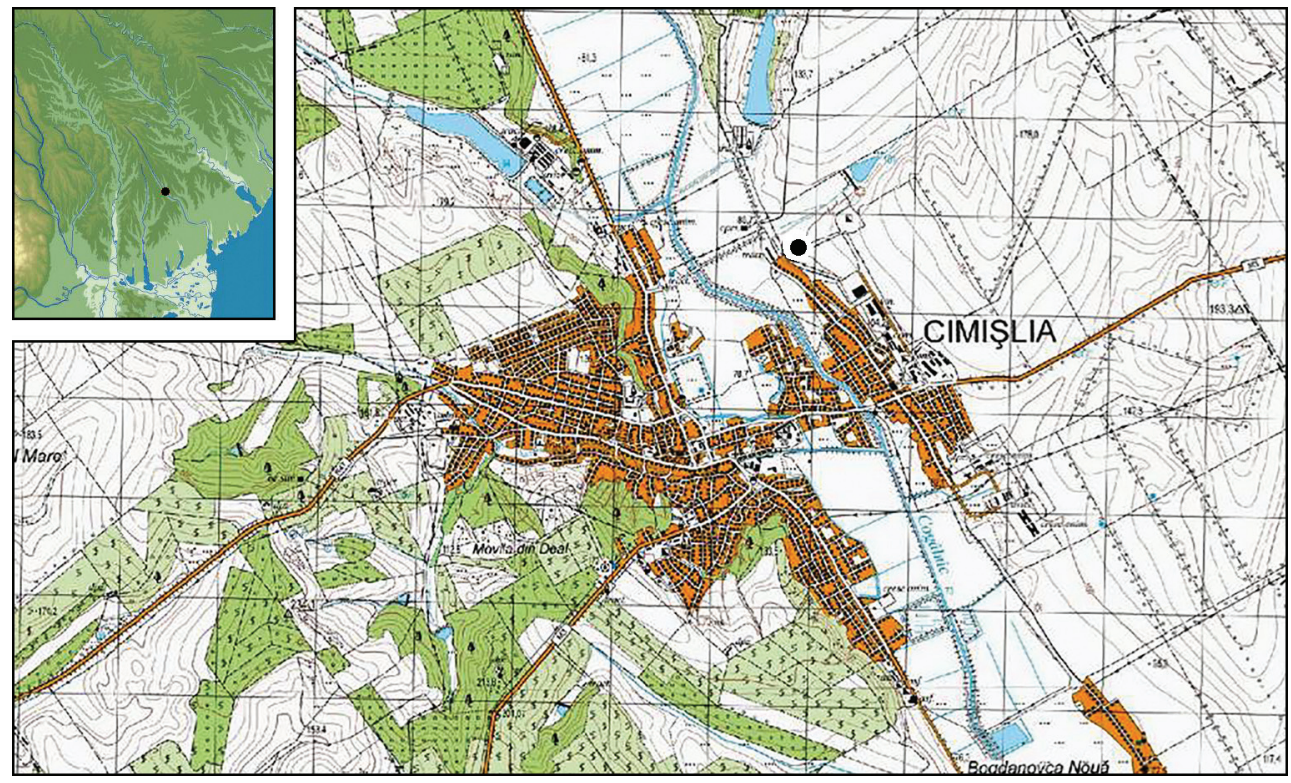

Fig. 1. The town Cimişlia in the southern Republic Moldova and the location of the burial mound 8

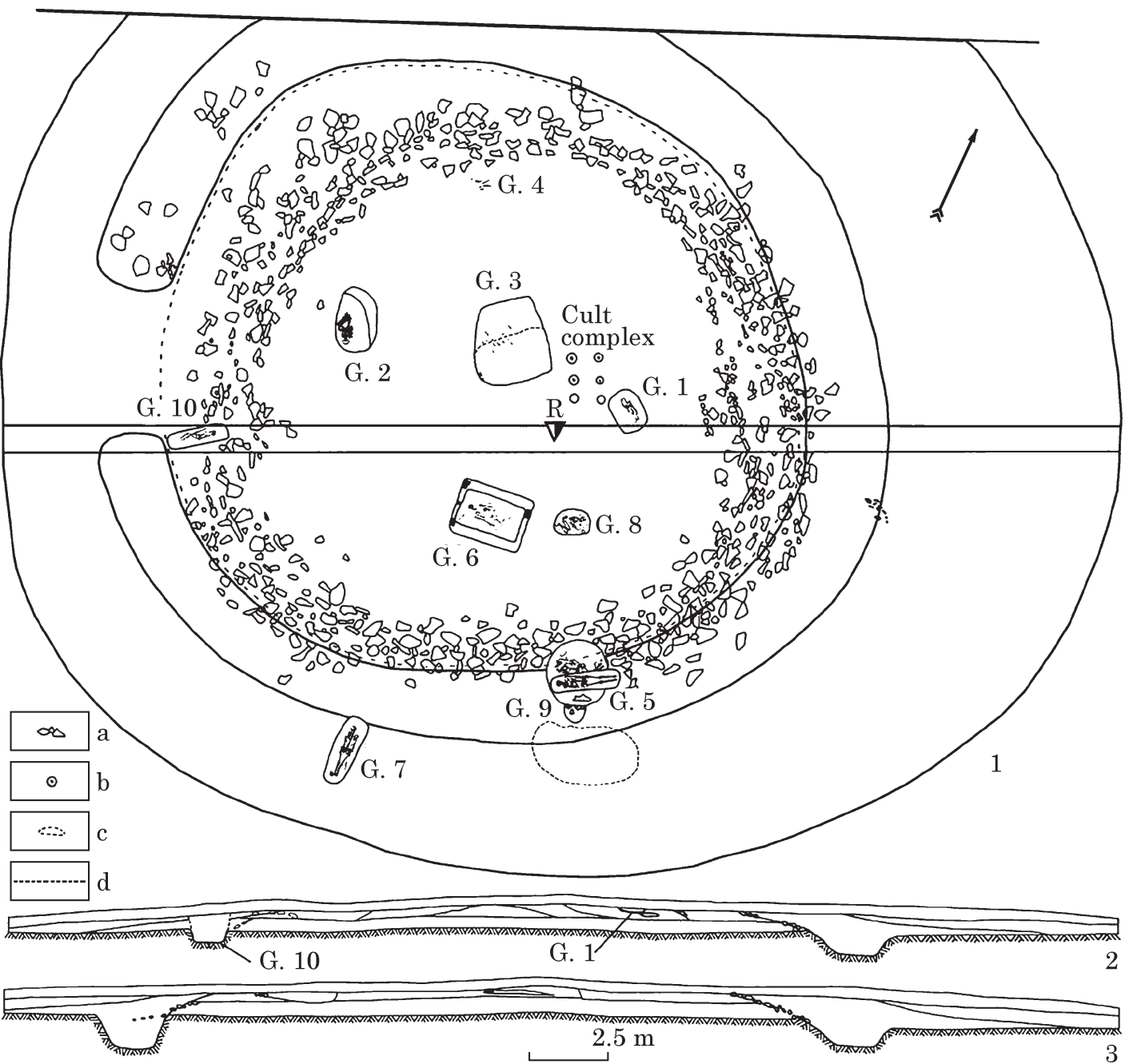

Fig. 2. Mound 8 in Cimişlia: 1 - plan of graves (G. 1-10) and other complexes; 2 - W-E profile (view from the north); $3-\mathrm{E}-\mathrm{W}$ profile (view from the south). Symbols: a - stones; b - the pits of the cult complex; $\mathrm{c}$ - the soil from tomb 9 ; $\mathrm{d}$ - the border of the first mound 
Table 1. Overview of the character and the relative chronology of all features excavated in Mound 8

\begin{tabular}{|c|c|c|}
\hline Feature & Brief description & Archaeological dating \\
\hline Grave 1 & $\begin{array}{l}\text { Oval grave pit, oriented NW-SE, probably male, } 30-35 \text { years, in crouched } \\
\text { position on the right side, ochre staining, no inventory }\end{array}$ & Yamnaya \\
\hline Grave 2 & $\begin{array}{l}\text { Oval grave pit, oriented } \mathrm{S}-\mathrm{N} \text {, male, } 40-50 \text { years, in crouched position on } \\
\text { the left side, ochre staining, } 1 \text { pot }\end{array}$ & Zhivotilovka \\
\hline Grave 3 & $\begin{array}{l}\text { Primary grave, trapezoid grave pit, fragmented skeleton, probably male and } \\
20-30 \text { years old, no inventory }\end{array}$ & Late Eneolithic \\
\hline Grave 4 & Only some bones were preserved. Cranial bones point to female, ca 20 years & Undetermined \\
\hline Grave 5 & Oval grave pit, oriented SWW-NEE, in supine position, male, $30-40$ years & Late Turanic period \\
\hline Grave 6 & $\begin{array}{l}\text { Rectangular grave pit with a ledge, oriented } \mathrm{W}-\mathrm{E} \text {, male, } 20-25 \text { years, in } \\
\text { crouched position on the right side, ochre staining, a piece of ochre }\end{array}$ & $\begin{array}{l}\text { Yamnaya, principal } \\
\text { grave of Yamnaya-cul- } \\
\text { ture type in the mound }\end{array}$ \\
\hline Grave 7 & $\begin{array}{l}\text { Oval grave pit, oriented } \mathrm{N}-\mathrm{S} \text {, in supine position, female, } 30-35 \text { years, } \\
1 \text { pot, } 40 \text { glass beads }\end{array}$ & Sarmatian \\
\hline Grave 8 & $\begin{array}{l}\text { Oval grave pit, oriented } \mathrm{E}-\mathrm{W} \text {, male, } 14-15 \text { years, in crouched position on } \\
\text { the left side, ochre staining, } 1 \text { pot, } 1 \text { flint borer, } 1 \text { flint flake }\end{array}$ & Zhivotilovka \\
\hline Grave 9 & $\begin{array}{l}\text { Catacomb grave, oriented } \mathrm{E}-\mathrm{W} \text {, male lying on back with slightly flexed } \\
\text { legs, } 16-18 \text { years, } 1 \text { animal bone }\end{array}$ & Catacomb \\
\hline Grave 10 & $\begin{array}{l}\text { Rectangular grave pit, oriented, NE-SW, female, } 6 \text { years, in supine posi- } \\
\text { tion, } 1 \text { spindle whorl, } 2 \text { silver head rings, a bracelet made of } 24 \text { carnelian } \\
\text { and } 8 \text { glass beads, } 14 \text { carnelian beads, } 34 \text { glass beads and } 1 \text { bead of rock } \\
\text { crystal at various places on grave bottom }\end{array}$ & Sarmatian \\
\hline $\begin{array}{l}\text { Accumu- } \\
\text { lation } 1\end{array}$ & $\begin{array}{l}\text { In the W part, } 13 \text { bones Equus caballus, } 69 \text { Bos taurus, } 1 \text { fragment } \\
\text { Unio sp., } 4 \text { ceramic fragments }\end{array}$ & $\begin{array}{l}\text { Late Medieval or mod- } \\
\text { ern period }\end{array}$ \\
\hline $\begin{array}{l}\text { Accumu- } \\
\text { lation } 2\end{array}$ & $\begin{array}{l}15 \text { bones Canis familiaris, } 13 \text { bones Bos taurus, } 5 \text { ceramic fragments and a } \\
\text { stone slab }\end{array}$ & $1^{\text {st }}-2^{\text {nd }}$ cent. $\mathrm{AD}$ \\
\hline Ditch & $\begin{array}{l}\text { Ring ditch with an inner diameter of } 20 \mathrm{~m} \text { and outer diameter of } 26 \mathrm{~m} \text {, } \\
2-2.6 \mathrm{~m} \text { wide and } 1.2-1.5 \mathrm{~m} \text { deep, numerous bones, made up largely of } \\
\text { Ovis aries, followed by Bos taurus, Cervus elaphus }\end{array}$ & Late Eneolithic \\
\hline $\begin{array}{l}\text { Cult } \\
\text { structure }\end{array}$ & 6 postholes in the centre, in rectangular form & Late Eneolithic \\
\hline $\begin{array}{l}\text { Stone «en- } \\
\text { closure» }\end{array}$ & $\begin{array}{l}\text { Following the form of the ditch, inner diameter: } 14 \mathrm{~m} \text {, black and greyish } \\
\text { stones lying on the ancient surface }\end{array}$ & Late Eneolithic \\
\hline
\end{tabular}

from the ditch. A relatively large wood sample was given to Dr. Karl-Uwe Heussner at the natural science department (Naturwissenschaftliches Referat) of the German Archaeological Institute. He and his assistant, Alexander Janus, managed to detect more than 85 tree-rings in this piece of oak wood ${ }^{1}$. They took samples at three sites, and these were submitted to the Radiocarbon Laboratory as separate samples. Sample 8G contains tree-rings close to the sapwood, sample $8 \mathrm{E}$ was taken 40 rings away from 8G. Sample 8F was taken another 40 rings further inward.

Results. The results of the radiocarbon analyses are shown in table 2 . We calibrated the radiocarbon dates that we received using the program OxCal, version 4.4.2. For the purposes of this paper, we have assigned the samples to three groups on the basis of the BP dates obtained for

1. The authors thank both, Dr. Karl-Uwe Heussner and his assistant, for this generous support. them. The first group contains the findings for the samples from Graves 3 and 4 as well as those from the cult complex and the ditch. After calibration, the dates in this group fall into the first half of the $4^{\text {th }}$ mill. BC (fig. 4). The second group represents the graves attributed to Zhivotilovka culture, which yielded dates in the second half of the $4^{\text {th }}$ mill. BC. The two burials of the Yamnaya culture form the last group, the date ranges obtained for these burials differ, but both fall within the period $3100-2650$ cal. BC.

Some of the results from this first calibration accord with archaeological expectations, while others were surprising. The results obtained for Grave 4 allow it to be assigned to the Late Eneolithic. Moreover, the date range obtained for the wood samples taken from the oak wood from one of the postholes of the cult complex is synchronous with the ranges obtained for Graves 3 and 4. The range obtained for the middle part of the tree-ring sequence (sample $8 \mathrm{E}$ ) is relatively long, 

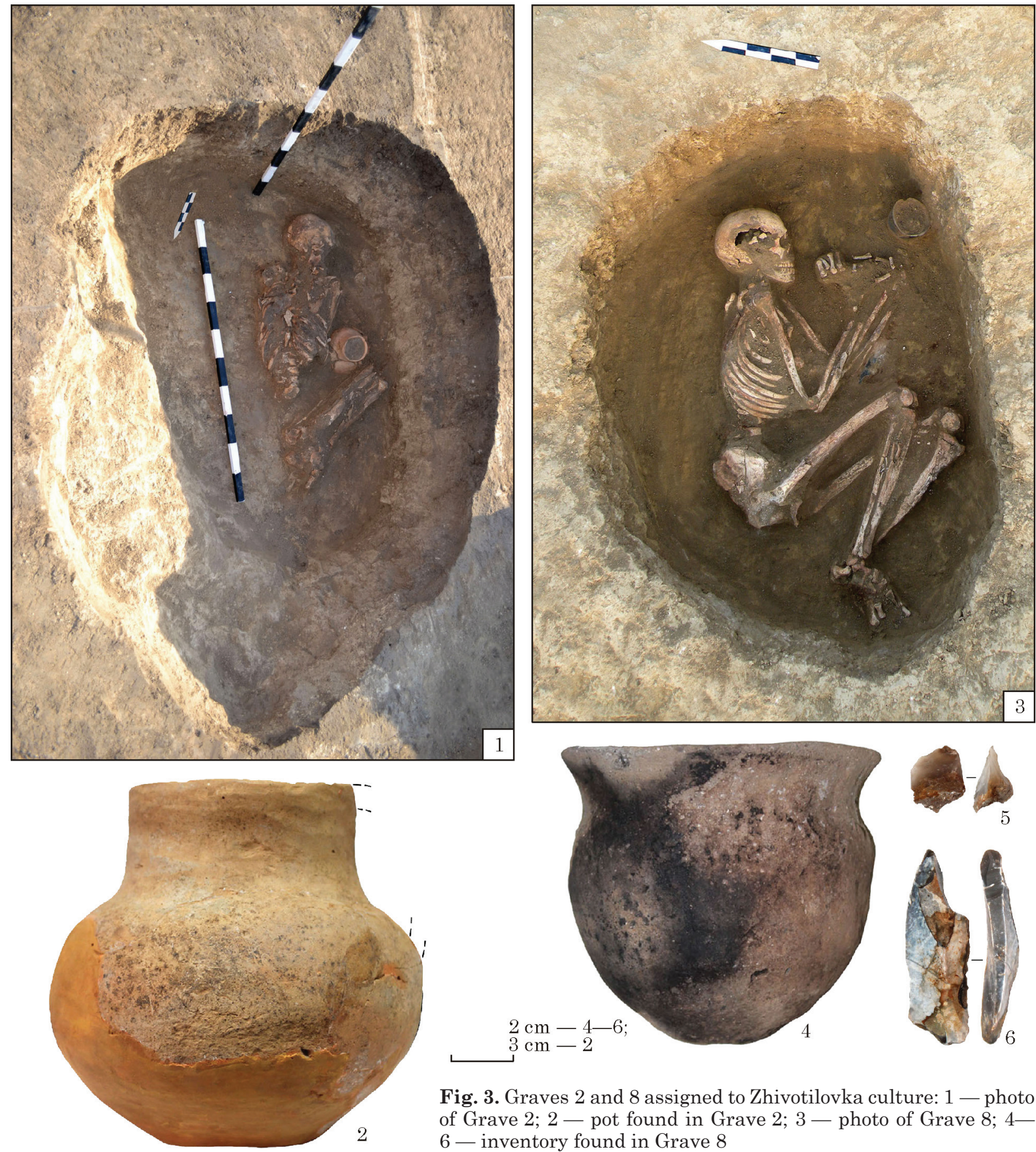

Fig. 3. Graves 2 and 8 assigned to Zhivotilovka culture: 1 - photo of Grave 2; 2 - pot found in Grave 2; 3 - photo of Grave 8; 4 6 - inventory found in Grave 8

however. Obviously, the wood sample was too small and the amount of carbon it contained was insufficient to allow a higher resolution (table 2). It was possible to date the ditch to the Late Eneolithic as well. The results for the two graves of the Zhivotilovka culture show almost the same date ranges after calibration, and these ranges correspond with the known dates for this cultural group. The comparatively early dates obtained for Grave 1, which is associated with the Yamnaya culture, were surprising, however. This grave was dated to $3265-2913 \mathrm{cal}$. BC, which would make it much older than Grave 6, the other Yamnaya-culture burial. However, according to the excavators, Grave 6 should be regarded as a constructed in the period of the Yamnaya culture in conjunction with the creation of a second layer, thus increasing the height and the diameter of the tumulus.

In a next step, we performed Bayesian modelling to refine our understanding of the chronology of the mound. Bayesian analysis of radiocarbon datasets is a tool used to increase the resolution of date ranges by factoring in additional information about the sequence of events, meaning, in this context, the relative timing of burials and other features. In the present case, the relevant information base consists of the information provided 
Table 2. Detailed information on the radiocarbon dating of the series of samples from features / burials in Mound 8 in Cimişlia (see fig. 4 for calibrated dates)

\begin{tabular}{|c|c|c|c|c|c|}
\hline \multirow{2}{*}{$\begin{array}{l}\text { Sample } \\
\text { name }\end{array}$} & \multirow[b]{2}{*}{ Lab. No } & \multirow[b]{2}{*}{ Age ${ }^{14} \mathrm{C}, \mathrm{BP}$} & \multicolumn{2}{|l|}{ Calibrated dates } & \multirow{2}{*}{$\begin{array}{c}\text { Remark, } \\
\% \mathrm{~N}, \% \mathrm{C}, \% \text { coll }\end{array}$} \\
\hline & & & BC (\%) & $\begin{array}{l}\text { Probabi- } \\
\text { lity, \% }\end{array}$ & \\
\hline Grave 8 & Poz-121008 & $4475 \pm 35$ & $\begin{array}{l}3331 \text { (45.7) 3215, } 3185 \text { (10.0) 3157, } 3126 \text { (12.5) } 3093 \\
3341 \text { (87.1) 3083, } 3067 \text { (8.3) } 3027\end{array}$ & $\begin{array}{l}68.2 \\
95.4\end{array}$ & $2.1,6.8,0.9$ \\
\hline Ditch & |Poz-121009 & $4860 \pm 35$ & $\begin{array}{l}3695 \text { (15.4) 3679, } 3668 \text { (52.8) } 3636 \\
3708 \text { (85.0) 3631, } 3578 \text { (0.6) 3573, } 3566 \text { (9.8) } 3536\end{array}$ & $\begin{array}{l}68.2 \\
95.4\end{array}$ & $1.7,7,5.9$ \\
\hline Grave 6 & |Poz-121011 & $4200 \pm 30$ & $\begin{array}{l}2886 \text { (20.0) 2861, } 2808 \text { (40.5) 2757, } 2719 \text { (7.7) } 2706 \\
2894,(27.1) 2841,2814 \text { (68.3) } 2678\end{array}$ & $\begin{array}{l}68.2 \\
95.4\end{array}$ & $0.8,3.8,3.7$ \\
\hline Grave 4 & |Poz-121047 & $4965 \pm 35$ & $\begin{array}{l}3782(68.2) 3702 \\
3905(3.4) 3880,3801(92.0) 3655\end{array}$ & $\begin{array}{l}68.2 \\
95.4\end{array}$ & $0.6,4.4,4.5$ \\
\hline Grave 3 & |Poz-121182 & $4955 \pm 35$ & $\begin{array}{l}3775(68.2) 3695 \\
3798(95.4) 3652\end{array}$ & $\begin{array}{l}68.2 \\
95.4\end{array}$ & $2.1,7.8,3.1$ \\
\hline Grave 2 & Poz-121048 & $4520 \pm 35$ & $\begin{array}{l}3350 \text { (13.2) 3321, } 3272 \text { (2.1) 3267, } 3236 \text { (29.9) 3170, } \\
3164(23.1) 3114 \\
3359 \text { (33.4) 3262, } 3252(62.0) 3098\end{array}$ & $\begin{array}{l}68.2 \\
95.4\end{array}$ & $1.1,5.1,3$ \\
\hline Grave 1 & |Poz-121089 & $4400 \pm 30$ & $\begin{array}{l}3087 \text { (17.8) 3059, } 3030 \text { (15.8) 3005, } 2990 \text { (34.6) } 2930 \\
3262 \text { (1.0) 3254, } 3099 \text { (94.4) 2917 }\end{array}$ & $\begin{array}{l}68.2 \\
95.4\end{array}$ & $2.2,8,2.2$ \\
\hline $\begin{array}{l}\text { Cult struc- } \\
\text { ture } 8 \mathrm{~F}\end{array}$ & Poz-123465 & $5060 \pm 35$ & $\begin{array}{l}3942 \text { (30.5) 3895, } 3882 \text { (17.4) 3855, } 3845 \text { (6.2) 3834, } \\
3822 \text { (14.1) } 3800 \\
3958 \text { (95.4) } 3780\end{array}$ & $\begin{array}{l}68.2 \\
95.4\end{array}$ & - \\
\hline $\begin{array}{l}\text { Cult struc- } \\
\text { ture } 8 \mathrm{E}\end{array}$ & Poz-123463 & $4850 \pm 90$ & $\begin{array}{l}3761 \text { (4.1) 3741, } 3731 \text { (1.0) 3726, } 3715 \text { (35.4) 3619, } \\
3611(27.8) 3521 \\
3911 \text { (2.0) 3878, } 3803 \text { (84.2) 3494, } 3467 \text { (9.2) } 3375\end{array}$ & $\begin{array}{l}68.2 \\
95.4\end{array}$ & $\begin{array}{l}\text { Very small, } \\
0.07 \mathrm{mgC}\end{array}$ \\
\hline $\begin{array}{l}\text { Cult struc- } \\
\text { ture } 8 \mathrm{G}\end{array}$ & Poz-123462 & $4920 \pm 50$ & $\begin{array}{l}3761 \text { (11.1) 3741, } 3731 \text { (2.8) 3726, } 3715 \text { (54.2) } 3649 \\
3895 \text { (1.1) 3882, } 3800 \text { (94.3) 3636 }\end{array}$ & $\begin{array}{l}68.2 \\
95.4\end{array}$ & Small, $0.2 \mathrm{mgC}$ \\
\hline
\end{tabular}

OxCal v4.4.2 Bronk Ramsey (2020); r:5 Atmospheric data from Reimer et al. (2020)

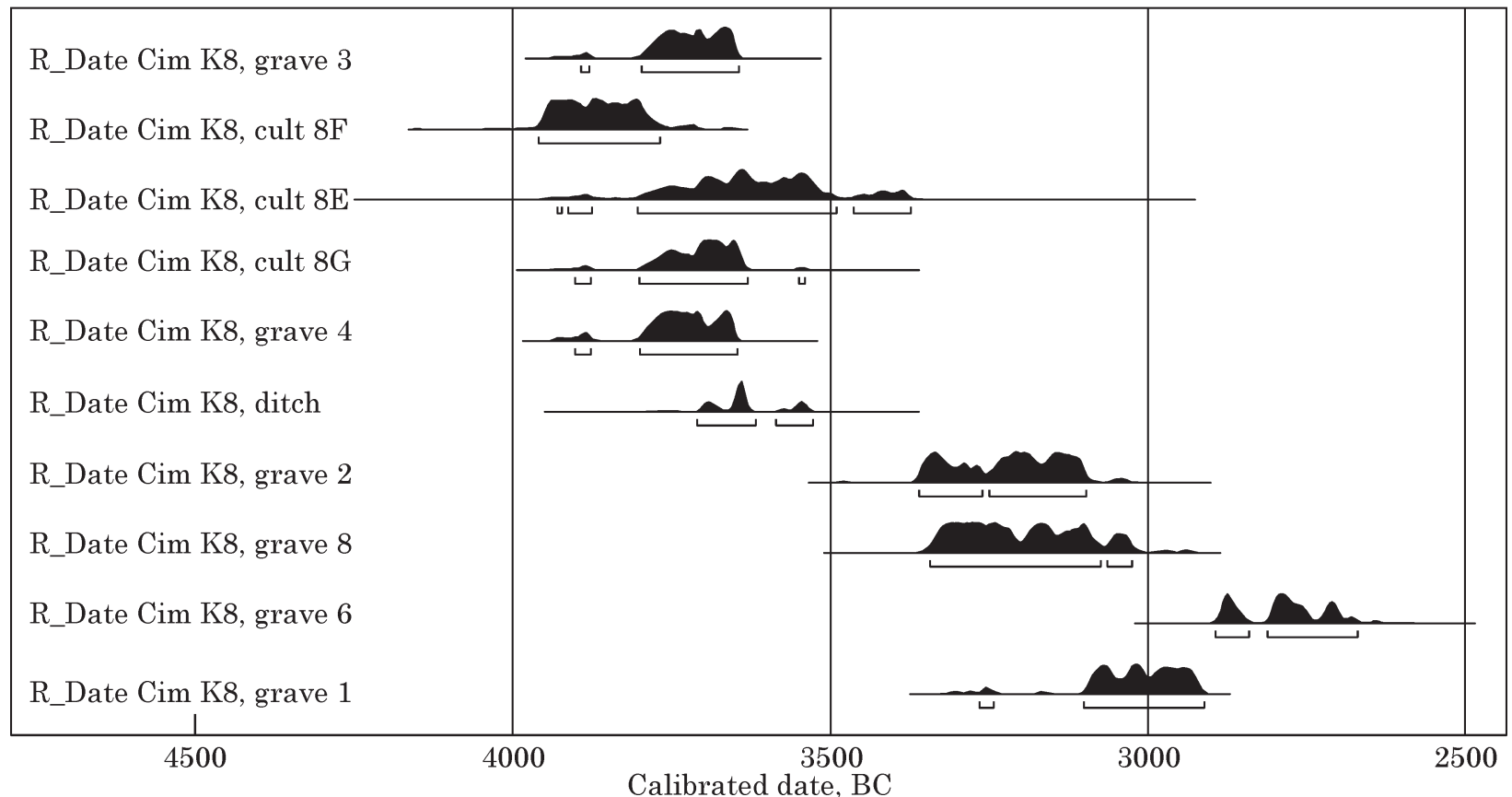

Fig. 4. Series of ten calibrated radiocarbon date ranges obtained for complexes found in Mound 8 at Cimişlia (see table 2 for specific date ranges) 
Fig. 5. Bayesian model of the radiocarbon dated complexes in Mound 8 at Cimişlia (see table 3 for specific date ranges

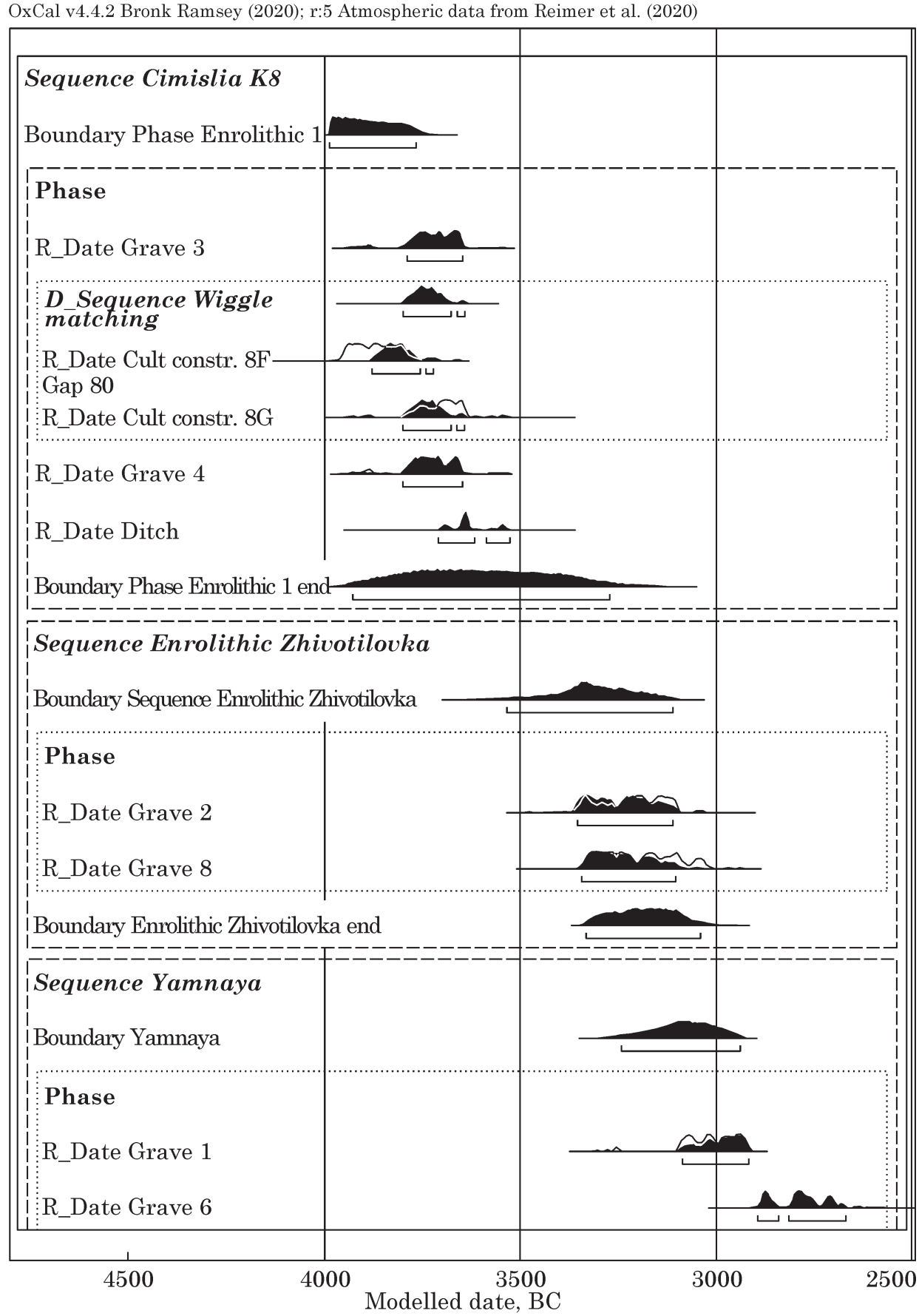

by the stratigraphy of the mound, which, as noted above, is very limited, and the relative chronologies established for the cultures to which many of the individual features have been attributed archaeologically. We ran multiple Bayesian analyses using parameters describing different possible sequences for the construction of the features (i. e. different chronological models), to determine which of these sequences combined with the radiocarbon datasets in statistically persuasive ways. Fig. 5 depicts the model that resulted in a statistically robust sequence. Table 3 details the model further. The model was defined as follows: Three phases were defined, Late Eneolithic, Final Eneolithic (designated "Eneolithic Zhivotilovka" in table 3) and Yamnaya culture. Then each of the features was assigned to one of them: Graves 3 and 4 and the ditch, as well as the ring of stones and the cult structure were assigned to the first of these phases based on the mound's stratigraphy. The result for the wood sample $8 \mathrm{E}$, (the one yielding a comparatively large date range) was omitted from the analysis and a parameter defining the temporal separation between the other two samples as 80 years (because these two sample sites were separated by 80 tree-rings) was added.

Discussion. With $95.4 \%$ probability, the oldest grave, Grave 3, was built between 3800 and 3647 cal. BC. No temporal difference between it 
Table 3. Detailed information about the Bayesian model of radiocarbon dates of Mound 8 at Cimişlia (see fig. 5 for calibrated dates)

\begin{tabular}{|c|c|c|c|c|c|c|c|c|c|c|c|c|c|}
\hline \multirow{2}{*}{$\begin{array}{l}\text { Name } \\
\text { Show all } \\
\text { Show structure }\end{array}$} & \multirow{2}{*}{ 蚝 } & \multicolumn{3}{|c|}{ Unmodelled (BC/AD) } & \multicolumn{3}{|c|}{ Modelled (BC/AD) } & \multicolumn{4}{|c|}{$\begin{array}{l}\text { Indices } \\
A_{\text {model }}=92 \\
A_{\text {overall }}=95.5\end{array}$} & \multirow{2}{*}{$\begin{array}{l}\text { Select } \\
\text { All } \\
\text { Visible }\end{array}$} & \multirow{2}{*}{$\begin{array}{l}\text { Page } \\
\text { break }\end{array}$} \\
\hline & & from & to & $\%$ & from & to & $\%$ & Acomb & A & $\mathbf{L P}$ & C & & \\
\hline$\nabla$ Sequence Cimislis K8 & 拝 & & & & & & & & & & & $\nabla_{2}^{2}$ & \\
\hline Boundary Phsse Eneolithic 1 & 拝 & & & & -3989 & -3788 & 95.4 & & & & 99.3 & $\square_{3}$ & \\
\hline$\nabla$ Phase & 前 & & & & & & & & & & & $\square_{4}$ & \\
\hline R_Date Grave 3 & EE & -3891 & -3846 & 95.4 & -3790 & -3848 & 95.4 & & 102.9 & & 98.5 & $\square_{5}$ & \\
\hline$\nabla$ D_Sequence Wiggle matching & 拝 & -3801 & -3841 & 95.4 & -3800 & -3642 & 95.4 & 81 & & & 97.3 & $\square_{6}$ & \\
\hline R_Date Cult $\infty$ nstr. 8F & 垔 & -3980 & -3771 & 95.4 & -3880 & -3722 & 95.4 & & 88.7 & & 97.3 & V7 & \\
\hline R_Date Cult $\infty$ nstr. 8G & 青 & -3903 & -3543 & 95.4 & -3800 & -3842 & 95.4 & & 84.4 & & 97.3 & $\square 8$ & \\
\hline R_Date Grave 4 & 垔 & -3903 & -3647 & 95.4 & -3800 & -3647 & 95.4 & & 103.5 & & 97.7 & $\checkmark 9$ & \\
\hline R_Date Ditch & 玗 & -3711 & -3529 & 95.4 & -3711 & -3528 & 95.4 & & 99.1 & & 97.3 & $\square_{10}$ & \\
\hline Boundary Phase Eneolithic 1 end & 垔 & & & & -3930 & -3274 & 95.4 & & & & 97.9 & $\square_{11}$ & \\
\hline V Sequence Sequence Eneolithic Zhivotilovks & 晅 & & & & & & & & & & & $\square^{12}$ & \\
\hline Boundary Sequence Eneolithic Zhivotilovka & 琲 & & & & -3533 & -3113 & 95.4 & & & & 98.5 & $\square^{13}$ & \\
\hline$\nabla$ Phase & 动 & & & & & & & & & & & $V^{14}$ & \\
\hline R_Date Grave 2 & 玨 & -3381 & -3099 & 95.4 & -3358 & -3111 & 95.4 & & 97.6 & & 98.5 & $\square^{15}$ & \\
\hline R_Date Grave 8 & E三 & -3344 & -3028 & 95.4 & .3343 & -3104 & 95.4 & & 107.2 & & 98.7 & $\square^{16}$ & \\
\hline Boundary Eneolithic Zhivotilovks end & 決 & & & & -3331 & -3041 & 95.4 & & & & 97.3 & $\square^{17}$ & \\
\hline$\nabla$ Sequence Yamnaya & 邦 & & & & & & & & & & & $\nabla_{18}$ & \\
\hline Boundary Yamnaya & EE & & & & -3243 & -2939 & 95.4 & & & & 99.1 & $\nabla_{19}$ & \\
\hline$\nabla$ Phase & 琒 & & & & & & & & & & & $\square_{20}$ & \\
\hline R_Date Grave 1 & 运 & -3265 & -2913 & 95.4 & -3087 & -2917 & 95.4 & & 105.9 & & 98.8 & $\nabla_{21}$ & \\
\hline R_Date Grave 6 & 球 & -2895 & -2871 & 95.4 & .2895 & -2871 & 95.4 & & 99.4 & & 98.7 & $\nabla_{22}$ & \\
\hline
\end{tabular}

and the cult structure can be detected on the basis of the radiocarbon data. This fact combined with the direct spatial proximity of the two complexes suggests that they existed simultaneously. Similar structures are known in the region northwest of the Black Sea, in Krasnoe (Grigoriopol district, Republic of Moldova), Sărăteni (Hânceşti district, Republic of Moldova), Cazaclia (Gagauzia, Republic of Moldova) and in the Kubey burial ground (Bolgrad district, Odessa region, Ukraine). Such constructions have also been documented in the Dnieper Basin and the Molochnaya River, at Stari Kodaky (Nikopol district, Dnipropetrovsk region, Ukraine), Nikopol (Nikopol district, Dnipro region, Ukraine) and Novopilipivka (Melitopol district, Ukraine, Zaporozhye region, Ukraine). A comparable cult structure was excavated in No. 29 of the tumulus group Khutor Shevchenko in the Nikopol district of Ukraine several years ago (Черных, Дараган 2014, с. 212-218). It consisted of nine postholes arranged in a square, all of which were over $1.0 \mathrm{~m}$ deep and contained construction elements of various kinds. On the basis of stratigraphy of this mound, the excavators
L. A. Chernykh and M. N. Daragan assigned this cult complex to the burials of the Middle Eneolithic in Mound 29. They published radiocarbon data for some of these graves, which indicate that they are synchronous or slightly younger (Черных, Дараган 2014, с. 501, табл. 1) than the features from the tumulus of Cimişlia, according to the time spans we obtained for them. Cult structures of which the postholes are still preserved, have been rarely discovered in other tumuli and seem to be exclusively related to Eneolithic burials (Черных, Дараган 2014, с. 273-275). The postholes of Cimişlia are a further confirmation for the existence of some kind of structures, but as the only preserved remnants of them are postholes, it is not possible to say much about their appearance.

There are not enough radiocarbon dates to permit a robust absolute chronology of cult structures of this type in the region northwest of the Black Sea. Dates which have been obtain include those from: two wooden samples collected from the posts of the cult assemblages from Krasnoe (Лy-2455, $5180 \pm 30$ BP) and Sărăteni 
(Лу-2454, $5140 \pm 40 \mathrm{BP})$, whose date ranges are quite close to one another (Яровой 2000, с. 152). An even earlier date was obtained for Grave 6, Mound 14 from the Semyonovka group of burial mounds (Belgorod-Dnestrovskiy district, Odessa region, Ukraine): Ки-2165, $5400 \pm 60$ BP, 43384084 cal. BC (68.2 \%) (Петренко, Ковалюх 2003, c. 109). Unfortunately, the radiocarbon dates obtained for the eponymous mound at Hadjider I, Mound 6, Grave 4 (Belgorod-Dnestrovskiy district, Odessa region, Ukraine) are very far from those mentioned above (Ki-9528, 3617-3349 cal. BC), a circumstance probably caused by an anomaly. From two other burials, which V. G. Petrenko has proposed categorising as early barrow graves in the "post-Stog» horizon, the following data were obtained: Katarzhino Mound 1, Grave 10 (Ivanivka district, Odessa region, Ukraine) $4950 \pm 70 \mathrm{BP}, 3793-3655 \mathrm{cal}$. BC (Ki-9523) and Koshary III Mound 3, Grave 6 (Kominternivske district, Odessa region, Ukraine) $-4720 \pm 80 \mathrm{BP}$, 3631-3377 cal. BC (Петренко, Ковалюх 2003, c. 107-109). In addition, the Cernavoda I cultural level in Orlovka (Reni district, Odessa region, Ukraine) was dated to the first half of the $4^{\text {th }}$ millennium BC (Govedarica, Manzura 2015, s. 456).

Grave 4, which could not be classified archaeologically due to the absence of grave goods and poor state of preservation, can now be reliably assigned to the first phase of the tumulus. The calibrated date ranges are relatively broad in the model, covering about 150 years. Graves 3 and 4 and the cult complex could have been built by persons of different generations. However, there is no evidence that all of these features were not laid out within a few years of one another, i. e. without major interruptions. Only the ring ditch that encloses these Late Eneolithic complexes seems to date to a somewhat more recent period. Construction of the first mound started with the ring ditch.

It appears that after Graves 3 and 4 and the cult complex were built, Mound 8 was not used again for at least 200 years. The next graves to be constructed there can be assigned to the Zhivotilovka culture (fig. 3). These two graves yielded almost identical calibrated date ranges between 3356 and 3104 cal. BC. They fit well into the chronological frame of Trypillya C2 phase and of the Final Eneolithic in the steppe zone north of the Black Sea (Rassamakin 2002). So far, very few radiocarbon data are available for the Zhivotolovka culture (Rassamakin 2011). Of the six dates that Yuri Ya. Rassamakin has collated, five fall into the second half of the 4 th millennium BC after calibration, and are thus more or less synchronous with Graves 2 and 8 from Cimişlia. Both graves show the typical characteristics of Zhivotilovka burials (fig. 3). The deceased were buried on their left side and stained with ochre. Each of them was equipped with a vessel (fig. 3:
$2,4)$. The inventory of Grave 8 involved two flint artefacts.

At present, Zhivotilovka complexes have been reported for over 70 sites spread between the Lower Don and the Carpathians. Their appearance in the North Pontic steppe is interpreted as a consequence of "prosperous societies with a high level of economic and social organization» represented by the Usatovo culture in the northwest of the Black Sea and Maykop culture in the Caucasus (Manzura 2016, s. 72).

It appears that the addition of the second layer to the tumulus did not occur in the Final Eneolithic, but later, in the period of the Yamnaya culture. At some point in that period, a second layer of earth was built above Grave 6. The date range for Grave 1 is significantly earlier than that for Grave 6, indicating that the former is one of the very early burials of the Yamnaya culture. It was obviously dug into the existing burial mound. With the help of Bayesian modelling, date range was shortened significantly, to 30862917 cal. BC. Perhaps only one or two generations later, between 2895 and 2671 cal. BC, the second grave of the Yamnaya culture, Grave 6, was built here. The relatively wide calibrated date ranges obtained for many of the Cimişlia graves are due to the numerous wiggles in the calibration curve. The absolute dates for Grave 6 fit in well with many other dates obtained for graves of the Yamnaya culture in the region northwest of Black Sea, which were compiled by S. Ivanova (Ivanova 2005, p. 38-39), and with those for graves in the northern Black Sea region compiled by Alla N. Nikolova and Yuri Ya. Rassamakin (Rassamakin, Nikolova 2008).

Conclusions. The radiocarbon data obtained for the series of early burials from Mound 8 at Cimişlia help to interpret the stratigraphic observations and the chronological attribution of some assemblages. The first chronological horizon of the mound is defined by Graves 3 and 4, the cult structure, the ring ditch and the ringshaped stone "platform». We have mentioned that the earliest burial mounds in the region northwest of the Black Sea are associated with such structures. They could be attributed to the Cernavoda I culture (Манзура 2013, c. 126139). The term "Cernavoda I culture», used to describe to a series of settlements and necropolises spread around Dobruja and eastern Muntenia, now replaces terms like "Hadjider» (Петренко 1989, c. 18-20), "the Bessarabian variant of the Cernavoda I culture» (Manzura 1993, c. 23-53) and «Hadjider-Cernavoda I» (Levitski, Manzura, Demcenco 1996, p. 62), which have been used in the past to describe to early burial mounds in the region northwest of the Black Sea. The radiocarbon results obtained for the oldest burials from Mound 8 from Cimislia together with dates for the ditch and the cult structure, show their dating to the first half of the $4^{\text {th }}$ millennium BC. These 
features are chronologically followed by the burials of the Zhivotilovka culture - Graves 2 and 8, which have been dated to the second half of the $4^{\text {th }}$ millennium BC. The Yamnaya culture burial in Grave 1, a secondary burial in the first level of the mound, was dated to $3265-2913$ cal. BC, and thus represents one of the other earliest Yamnaya burials in the region northwest of the Black Sea for which radiocarbon dating has been performed. Dates obtained for the other Yamnaya burial, Grave 6, broadly correspond with the absolute chronology of this culture in the area under study.

The information published here adds to the database of the absolute chronology of early barrow cultures in the region northwest of the Black Sea. Moreover, the authors plan to conduct in future similar studies on early burial mounds.

\section{ЛІТЕРАТУРА}

Иванова, С. И. 2005. Эпоха ранней бронзы Причерноморских степей. Revista arheologică, I, 1, с. 3443.

Манзура, И. В. 2013. Культуры степного энеолита. В: Бруяко, И. В., Самойлова, Т. Л. (ред.). Древние культурь Северо-Западного Причерноморья. Одесca, c. $115-153$.

Петренко, В. Г. 1989. Памятники энеолита и поворот эпохи к бронзовому веку в Северо-Западном Причерноморье. В: Петренко, В. Г. (ред.). История и археология Нижнего Подунавья (тезисы). Рени: Ренийская типографрия, с. 18-20.

Петренко, В. Г., Ковалюх, Н. Н. 2003. Новые данные по радиоуглеродной хронологии энеолита Северо-Западного Причерноморья. В: Корвін-Піотровський, О. Г., Круц, В. О., Рижов, С. М. (ред.). Трипільські поселення-гіганти в Украӥні. Київ: КорвінПресс, с. 102-110.

Черных, Л. А., Дараган, М. Н. 2014. Курганы эпохи энеолита-бронзы междуречья Базавлука, Соленой, Чертоллыка. Курганы Украины, 4. Киев: Олег Филюк.

Яровой, Е. В. 2000. Скотоводческое население Севего-Западного Причернолорья эпохи раннего металла. Диссертация д. и. н. Москва.

Govedarica, B, Manzura, I. 2015. The Copper Age Settlement of Kartal in Orlovka (Southwest Ukraine). In: Hansen, S., Raczky, P., Anders, A., Reingruber, A. (eds.). Neolithic and Copper Age between the Carpathians and the Aegean Sea. Chronologies and Technologies from the $6^{\text {th }}$ to the $4^{\text {th }}$ Millennium BCE. International Workshop Budapest 2012. Archäologie in Eurasien, 31. Bonn: R. Habelt, p. 437-457.

Levițki, O., Manzura, I., Demcenco, T. 1996. Necropola tumulară de la Sărăteni. Bibliotheca Thracologica, XVII. Bucureşti: Institutul Român de Tracologie.

Manzura, I. 1993. The East-West interaction in the mirror of the Eneolithic and Early Bronze cultures in north-west Pontic. Revista arheologică, 1, p. 23-53.

Manzura, I. 2016. North Pontic steppes at the end of the $4^{\text {th }}$ millennium BC: the epoch of broken borders. In: Zanoci, A., Kashuba, M., Kaiser, E. (eds.). Mensch, Kultur und Gesellschaft von der Kupferzeit bis zur frühen Eisenzeit im Nördlichen Eurasien. Beiträge zu
Ehren zum 60. Geburtstag von Eugen Sava. Tiragetia International I. Chişinău, p. 53-75.

Popovici, S., Ciobanu, S., Agulnikov, S., Noroc, I. 2016. Tumulul 8 de la Cimişlia. Considerații preliminare. Arheologia Preventiva în Republica Moldova, III, p. 19-28.

Rassamakin, Yu. 2002. Aspects of Pontic Steppe Development (4550-3000 BC) in the Light of the New Cultural-Chronological Model. In: Boyle, K., Renfrew, C., Levine, M. (eds.). Ancient interactions: east and west in Eurasia. Cambridge: MacDonald Institute, p. $49-73$.

Rassamakin, Ju. Ja. 2011. Zur absoluten Chronologie des Äneolithikums in den Steppen des Schwarzmeergebietes anhand neuer ${ }^{14} \mathrm{C}$-Daten. In: Sava, E., Govedarica, B., Hänsel, B. (eds.). Der Schwarzmeerraum vom Äneolithikum bis in die Früheisenzeit (5000-500 v. Chr.). Prähistorische Archäologie in Südosteuropa, 27. Rahden: M. Leidorf, p. 80-100.

Rassamakin, Yu. Ya., Nikolova, A. V, 2008. Carpathian Imports and Imitations in Context of the Eneolithic and Early Bronze Age of the Black Sea Steppe Area. In: Biehl, P. F, Rassamakin, Yu. Ya. (eds.). Import and Imitation in Archaeology. Schriften des Zentrums für Archäologie und Kulturgeschichte des Schwarzmeerraums, 11. Langenweißbach: Beran, p. 51-87.

\section{REFERENCES}

Ivanova, S. I. 2005. Epokha rannei bronzy Prichernomorskikh stepei. Revista arheologică, I, 1, s. 34-43.

Manzura, I. V. 2013. Kultury stepnogo eneolita. In: Brujako, I. V., Samoilova, T. L. (ed.). Drevnie kultury Severo-Zapadnogo Prichernomoria. Odessa, s. 115-153.

Petrenko, V. G. 1989. Pamiatniki eneolita i povorot epokhi $\mathrm{k}$ bronzovomu veku v Severo-Zapadnom Prichernomore. In: Petrenko, V. G. (ed.). Istoriia i arkheologiia Nizhnego Podunavia (tezisy). Reni: Reni'skaia tipografiia, s. 18-20.

Petrenko, V. G., Kovaliukh, N. N. 2003. Novye dannye po radiouglerodnoi khronologii eneolita Severo-Zapadnogo Prichernomoria. In: Korvin-Piortovski, O. G., Kruc, V. O., Ryzov, S. M. (ed.). Trypilski poselennia-hihanty $v$ Ukraini. Kyiv: Korvin-Press, s. 102-110.

Chernykh, L. A., Daragan, M. N. 2014. Kurgany epokhi eneolita-bronzy mezhdurechia Bazavluka, Solenoi, Chertomlyka. Kurgany Ukrainy, 4. Kiev: Oleg Filiuk.

Iarovoi, E. V. 2000. Skotovodcheskoe naselenie Sevego-Zapadnogo Prichernomoria epokhi rannego metalla. Dissertatsiia d. i. n. Moskva.

Govedarica, B, Manzura, I. 2015. The Copper Age Settlement of Kartal in Orlovka (Southwest Ukraine). In: Hansen, S., Raczky, P., Anders, A., Reingruber, A. (eds.). Neolithic and Copper Age between the Carpathians and the Aegean Sea. Chronologies and Technologies from the $6^{\text {th }}$ to the $4^{\text {th }}$ Millennium BCE. International Workshop Budapest 2012. Archäologie in Eurasien, 31. Bonn: R. Habelt, p. 437-457.

Leviți, O., Manzura, I., Demcenco, T. 1996. Necropola tumulară de la Sărăteni. Bibliotheca Thracologica, XVII. Bucureşti: Institutul Român de Tracologie.

Manzura, I. 1993. The East-West interaction in the mirror of the Eneolithic and Early Bronze cultures in north-west Pontic. Revista arheologică, 1, p. 23-53.

Manzura, I. 2016. North Pontic steppes at the end of the $4^{\text {th }}$ millennium BC: the epoch of broken borders. In: Zanoci, A., Kashuba, M., Kaiser, E. (eds.). Mensch, Kultur und Gesellschaft von der Kupferzeit bis zur frühen Eisenzeit im Nördlichen Eurasien. Beiträge zu Ehren zum 60. Geburtstag von Eugen Sava. Tiragetia International I. Chişinău, p. 53-75.

Popovici, S., Ciobanu, S., Agulnikov, S., Noroc, I. 2016. Tumulul 8 de la Cimişlia. Considerații preliminare. Arheologia Preventiva în Republica Moldova, III, p. 19-28.

Rassamakin, Yu. 2002. Aspects of Pontic Steppe Development (4550-3000 BC) in the Light of the New Cultural- 
Chronological Model. In: Boyle, K., Renfrew, C., Levine, M. (eds.). Ancient interactions: east and west in Eurasia. Cambridge: MacDonald Institute, p. 49-73.

Rassamakin, Ju. Ja. 2011. Zur absoluten Chronologie de Äneolithikums in den Steppen des Schwarzmeergebietes an hand neuer ${ }^{14} \mathrm{C}-$ Daten. In: Sava, E., Govedarica, B., Hänsel, B. (eds.). Der Schwarzmeerraum vom Aneolithikum bis in die Früheisenzeit (5000 - 500 v. Chr.). Prähistorische Archäologie in Südosteuropa, 27. Rahden: M. Leidorf, p. 80-100.

Rassamakin, Yu. Ya., Nikolova, A. V, 2008. Carpathian Imports and Imitations in Context of the Eneolithic and Early Bronze Age of the Black Sea Steppe Area. In: Biehl, P. F Rassamakin, Yu. Ya. (eds.). Import and Imitation in Archaeology. Schriften des Zentrums für Archäologie und Kulturgeschichte des Schwarzmeerraums, 11. Langenweißbach: Beran, p. $51-87$.

\section{S. Popovici, E. Kaiser}

\section{A BURIAL MOUND IN THE TOWN OF CIMIŞLIA IN SOUTHERN PART OF THE REPUBLIC OF MOLDOVA: RELATIVE AND ABSOLUTE CHRONOLOGY OF THE BURIALS}

The grave mound 8 in the town Cimişlia, Republic Moldova, was situated on the first terrace of the small river Cogâlnic. Ten graves of the Eneolithic - Sarmatian periods, ditch and cult structure were discovered. Because of intensive ploughing activity, the mound was only $0.8 \mathrm{~m}$ in height, $36 \mathrm{~m}$ in diameter. It was one of a group of six burial mounds there. Based on the analysis of stratigraphy and a series of radiocarbon dates, the relative and absolute chronology of graves of the Eneolithic - Early Bronze Age is established.

The first group of burials - the Late Eneolithic time. The oldest grave, Grave 3, was built between 3800 and 3647 cal. BC. No temporal difference between it and the cult structure can be detected on the basis of the radiocarbon dates. This fact, combined with the direct spatial proximity of the two complexes suggests that they existed simultaneously. Similar structures are known in the region northwest of the Black Sea, the Dnieper region and Molochnaya river.

The second group of graves - the Zhivotilovka Culture. These two graves yielded almost identical calibrated date ranges between 3356 and 3104 cal. BC. They fit well into the chronological frame of Trypillya C2 phase and of the Final Eneolithic in the steppe zone north of the Black Sea.

The third group of graves - the Yamnaya Culture. The date range for Grave 1 is significantly earlier than that for Grave № 6, indicating that the former is one of the very early burials of the Yamnaya culture. It was obviously dug into the existing burial mound. With the help of Bayesian modelling, date range was shortened significantly, to 3086-2917 cal. BC. Perhaps only one or two generations later, between 2895 and 2671 cal. BC, the second grave of the Yamnaya culture, Grave 6, was built here.

The relatively wide calibrated date ranges obtained for many of the Cimislia graves are due to the numerous wiggles in the calibration curve. The absolute dates for Grave 6 fit in well with many other dates obtained for the graves of the Yamnaya culture in the region northwest of the Black Sea.

Keywords: Late Eneolithic, Zhivotilovka culture, absolute chronology, Yamnaya culture.

\section{C. Поповіч, Е. Кайзер}

\section{КУРГАН В МІСТІ ЧИМІШЛІЯ В ПІВ- ДЕННІЙ ЧАСТИНІ РЕСПУБЛІКИ МОЛДОВА: ВІДНОСНА ТА АБСО- ЛЮТНА ХРОНОЛОГІЯ ПОХОВАНЬ}

В кургані 8 в місті Чимішлія, Республіка Модова, досліджені десять поховань від енеоліту до сарматського періоду, рів та культова споруда. Курган розташований на першій терасі маленької р. Когильник. Висота кургану дорівнюе 0,8 м, діаметр 36 м, він інтенсивно розорювався, входив до групи з шести курганів. На підставі аналізу стратиграфії та серії радіовуглецевих дат встановлюеться відносна та абсолютна хронологія поховань доби енеоліту - раннього бронзового віку.

Перша група поховань - пізньоенеолітичного часу. Найдавніше поховання 3 датуеться між 3800 та 3647 рр. до н. е. На основі радіовуглецевих даних не можна виявити часової різниці між цим похованням та культовою спорудою. Цей фракт у поєднанні з безпосередньою просторовою близькістю двох комплексів свідчить про те, що вони існували одночасно. Подібні споруди відомі в регіоні на північний захід від Чорного моря, в басейні Дніпра та річці Молочній.

Друга група поховань - животилівської культури. Їх калібровані дати майже однакові - 3356 i 3104 cal. BC - i добре вписуються в хронологічну рамку трипільської фрази С2 та фрінального енеоліту в степовій зоні на північ від Чорного моря.

Третя група поховань - ямної культури. Діапазон дат для поховання 1 значно давніший, ніж поховання 6. Це вказуе на те, що перше е одним із дуже ранніх поховань ямної культури. Воно, очевидно, було впущене в існуючий курган. За допомогою Байесівського моделювання діапазон дат був значно скорочений до 3086-2917 cal. BC. Можливо, лише через одне-два покоління, між 2895 та 2671 рр. до н. е., поховання 6 ямної культури було здійснено.

Порівняно широкі калібровані діапазони дат, отримані для багатьох могил Чимішлії, зумовлені численними хитаннями на калібрувальній кривій. Абсолютні дати для поховання 6 добре поєднуються 3 багатьма іншими датами, отриманими для поховань ямної культури в регіоні на північний захід від Чорного моря.

Ключові слова: пізній енеоліт, животилівська культура, абсолютна хронологія, ямна культура.

Одержано 12.10.2020

КАЙЗЕР Ельке, Dr., професор, Інститут праісторичної археології, Берлінський вільний університет, Німеччина.

KAISER Elke, Dr., Professor of Institut für Praehistorische Archaeologie, Freie Universitaet Berlin, Germany.

ORCID: 0000-0003-0462-0189,

e-mail: ekaiser@zedat.fu-berlin.de.

ПОПОВІЧ Сергій, заступник керівника, Національна агенція археології, Кишинеу, Республіка Молдова.

POPOVICI Sergiu, deputy director, National Agency for Archaeology, Chişinău, Republic of Moldova.

ORCID: 0000-0002-8575-8667,

e-mail: sergiupopovici1986@gmail.com. 